\title{
Correction to: Two worlds apart? Export demand shocks and domestic sales
}

\author{
Aksel Erbahar ${ }^{1,2}$ (D) \\ Published online: 18 March 2021 \\ (c) Kiel Institute 2021
}

\section{Correction to: Review of World Economics (2020) 156:313-342 https://doi.org/10.1007/s10290-019-00364-z}

In the original publication of the article, the below sentence was missed to be added. It should read as follows

"This project has received funding from the project "Global Value Chains and Firm Performance in Developing Countries" of the Swiss National Science Foundation (Grant Number: 100018_159346)."

Publisher's Note Springer Nature remains neutral with regard to jurisdictional claims in published maps and institutional affiliations.

The original article can be found online at https://doi.org/10.1007/s10290-019-00364-z.

Aksel Erbahar

erbahar@ese.eur.nl

1 Erasmus School of Economics (ESE), Erasmus University Rotterdam, Rotterdam, The Netherlands

2 Tinbergen Institute, Amsterdam, The Netherlands 